STUDIA Z PRAWA WYZNANIOWEGO

Tom $24-2021$

DOI: https://doi.org/10.31743/spw.12733

RYSZARD SZTYCHMILER ${ }^{*}$

\title{
GWARANCJE WYCHOWANIA RELIGIJNEGO DZIECI W PRAWIE POLSKIM
}

The guarantees for the religious upbringing of children in Polish law

Streszczenie: Celem niniejszego artykułu jest odpowiedź na pytanie o wystarczalność gwarancji wychowania religijnego w obowiązującym prawie polskim. Rodzice mają naturalne prawo podejmowania działań zmierzających do ukształtowania swoich dzieci pod względem psychicznym, umysłowym, duchowym, moralnym, światopoglądowym i religijnym. Słusznie znalazło to odzwierciedlenie w polskich przepisach konstytucyjnych, które uniemożliwiają narzucanie wzorców wychowawczych, kształtowanie postaw i przekonań dzieci wbrew woli rodziców. Również postanowienia umów międzynarodowych poświęconych ochronie praw człowieka nie ograniczają się z reguły do generalnego zagwarantowania wolności myśli, sumienia i religii każdemu człowiekowi. Zawierają też zazwyczaj postanowienia chroniące prawo rodziców do decydowania o kierunku wychowania moralnego i religijnego swego potomstwa. W zgodzie z tymi standardami ukształtowano przepisy polskich ustaw oraz wydanych na ich podstawie aktów wykonawczych. Niezależnie od wyznania wszystkim zapewniono w szczególności możliwość korzystania z nauczania religii w szkołach. Można więc stwierdzić, że prawo rodziców do religijnego wychowania swych dzieci korzysta w Polsce z dość szerokiej ochrony. Jej ewentualne niedostatki mogą wynikać z niewłaściwego stosowania prawa. Kwestia ta zasługuje jednak na osobną analizę.

Słowa kluczowe: wychowanie religijne; wolność religijna; prawa człowieka; prawo wyznaniowe; nauczanie religii

* Ks. prof. dr hab., emerytowany profesor Wydziału Prawa i Administracji, Uniwersytet Warmińsko-MazurskiwOlsztynie,ul.Obitza 1,10-725Olsztyn,e-mail:Ryszard.Sztychmiler@ uwm.edu.pl. ORCID 0000-0001-6441-3291. 
Abstract: This article addresses the question of the sufficiency of the guarantees for religious upbringing in current Polish law. Parents have a natural right to take action in shaping the psychological, mental, spiritual, moral, philosophical and religious development of their children. This is rightly reflected in the Polish constitutional regulations, which prevent imposing patterns of upbringing and shaping children's attitudes and convictions against the will of their parents. Likewise, the provisions of the international agreements for the protection of human rights are usually not confined to general guarantees of the freedom of thought, conscience and religion of every person. They often protect parents' rights over their children's moral and religious upbringing. The Polish primary and secondary legislation in line with these standards. Irrespective of their religion, everyone is ensured the opportunity to receive religious education at school. It can thus be concluded that the right of parents to the religious upbringing of their children is afforded relatively broad protection in Poland. Its possible limitations may be due to improper application of the law. This issue, however, deserves a separate analysis.

Key words: religious upbringing; religious freedom; human rights; law on religion; religious education

\section{WPROWADZENIE}

Prawo do ochrony życia religijnego, wolności religijnej, a także prawo dzieci do otrzymania nauczania i wychowywania religijnego, w teorii nie podlegają dziś dyskusji. Również prawo rodziców do wychowania dzieci w duchu swoich przekonań należy do istotnych uprawnień wynikających z wolności religijnej, a historia wskazuje, jak zgubne mogą być konsekwencje prób zawłaszczenia tego prawa przez zideologizowane instytucje państwowe (III Rzesza, ZSRR).

W ostatnich latach bardzo aktywni stali się przedstawiciele filozofii neomarksistowskiej oraz ideologii gender, którzy z zasady sprzeciwiają się religii i wychowaniu religijnemu ${ }^{1}$. Uznają oni monogamiczne małżeństwo oraz wychowanie dzieci w rodzinie i w szkole zgodnie $\mathrm{z}$ przekonaniami rodziców za szkodliwe stereotypy. Do ich zwalczania i do promocji przeciwnych im wzorców wykorzystują m.in. różnorodne organizacje

1 Zob. Sztychmiler 2015b, 227-228. 
o charakterze międzynarodowym i krajowym oraz instrumenty prawne i finansowe, którymi one dysponują.

Ważną rolą prawa jest ochrona powszechnie uznawanych wartości, wśród których istotne miejsce zajmuje ochrona wolności religijnej oraz prawa do wychowania religijnego dzieci zgodnie z wolą rodziców. Warto więc zwrócić uwagę na współczesne zagrożenia tych wartości i podjąć próbę odpowiedzi na pytanie o poziom ochrony, jaką tym wartościom zapewniają przepisy obowiązujące w Polsce.

\section{ZAGROŻENIA WYCHOWANIA RELIGIJNEGO W POLSCE}

Za jeden ze znaków współczesnych czasów można uznać to, że nawet niektóre partie (nie mówiąc już o poszczególnych politykach) formalnie przyznające się do chrześcijaństwa angażują się we wdrażanie programów wywodzących się z poglądów Fryderyka Engelsa i Simone de Beauvoir, które lansowane są dziś przez środowiska feministyczne czy homoseksualne. Nietrudno w nich dostrzec na przykład powrót do idei kolektywnego wychowywania dzieci, szczególnie tych najmłodszych, co pozwoliłoby na latwe ich ukierunkowywanie zgodnie z propagowaną ideologią. Uzasadnione zdziwienie w tym kontekście wzbudza opinia, którą prof. Irena Lipowicz - jako Rzecznik Praw Obywatelskich - wyraziła w 2014 r. w piśmie adresowanym do minister Joanny Kluzik-Rostkowskiej w odniesieniu do programu „Równościowe przedszkole”. Nie podzielając zastrzeżeń zgłoszonych wobec tego programu przez Fundację, Rzecznik Praw Rodziców stwierdziła m.in., że „Konstytucja nie może gwarantować, i nie gwarantuje, że wiedza przekazywana w szkole będzie zgodna z przekonaniami rodziców”, „ustalanie i planowanie programu nauczania należy [...] co do zasady do kompetencji państwa”, a „rodzice mogą edukować swoje dzieci po szkole i w weekendy" ". Twierdzenia te pozostają jednak w sprzeczności

2 Pismo z dnia 24 kwietnia 2014 r. (I.800.1.2014.AM), https://bip.brpo.gov.pl/pl/content/do-men-ws-edukacji-antydyskryminacyjnej-w-przedszkolach [dostęp: 09.11.2021]. 
z prawami rodziców zagwarantowanymi m.in. w Konstytucji Rzeczypospolitej Polskiej³.

W debacie publicznej nie brakuje głosów ostrzegających przed zagrożeniami, które wynikają z promocji koncepcji wymierzonych przeciwko tradycyjnie postrzeganemu małżeństwu i rodzinie, w tym zwłaszcza ideologii gender. Były prefekt Kongregacji Wychowania Katolickiego, kardynał Zenon Grocholewski, wyraził na przykład pogląd, że szkoły kościelne nie mogą poddawać się wpływom tej ideologii, gdyż jest ona złem, „któremu należy się przeciwstawić", a zwiększanie jej oddziaływania określił jako „narzucanie niszczycielskiej idei”" . Z kolei Virginia Coda Nunziante, rzeczniczka włoskiego ruchu katolickiego „Rodzina Jutro”, zaapelowała o zdawanie sobie sprawy z niebezpieczeństwa tej ideologii i odpowiednie reagowanie. W przeciwnym wypadku „będziemy współwinni wywrócenia naszego społeczeństwa 5 .

\section{GWARANCJE ZAWARTE W KONSTYTUCJI RP}

Chociaż w Ustawie zasadniczej nie zdefiniowano takich pojęć jak religia, wychowanie, dziecko, rodzice czy rodzina, to unormowano tak fundamentalną kwestię jak wychowanie dzieci przez rodziców zgodnie z ich własnymi przekonaniami. Dla gwarancji wychowania religijnego najważniejsze są normy zapisane w art. $48 \mathrm{i}$ art. 53 Konstytucji RP.

Bardziej podstawowy wydaje się art. 53, w którym zawarto unormowania dotyczące wolności sumienia i religii, zapewniając ją każdemu. W ust. 3 tego artykułu odniesiono się do praw rodziców. Zagwarantowano im ,prawo do zapewnienia dzieciom wychowania i nauczania moralnego i religijnego zgodnie ze swoimi przekonaniami”, odsyłając jednocześnie do art. 48 ust. 1. Już powyższe oznacza, iż ustawodawca postanowił

3 Konstytucja Rzeczypospolitej Polskiej z dnia 2 kwietnia 1997 r., Dz. U. z 1997 r. $\mathrm{Nr} 78$, poz. 483 z późn. zm.

$4 \mathrm{PAP} / \mathrm{mh}, 2013$. Watykan: Ideologia gender jest groźna, https://deon.pl/kosciol/watykan-ideologia-gender-jest-grozna,206619 [dostęp: 09.11.2021].

5 Tamże. 
pozostawić podejmowanie decyzji w sprawie kierunku i treści wychowania etycznego i religijnego dzieci w gestii rodziców ${ }^{6}$.

Warto zauważyć, że w art. 53 ust. 1 Konstytucji RP „każdemu zapewnia się wolność sumienia i religii”. Ustrojodawca celowo nie użył tu określenia „obywatel”, którym w analogicznym kontekście posługiwała się Konstytucja PRL z 1952 r. ${ }^{7}$, zastępując je sformułowaniem „każdy”. Zabieg ten oznacza potwierdzenie paradygmatu aksjologicznego, zgodnie z którym - jak to przyjęto w wiążących Polskę umowach międzynarodowych - źródłem wolności sumienia i religii jest przyrodzona godność osoby ludzkiej, a nie wola ustawodawcy ${ }^{8}$.

Uprawnienie rodziców w zakresie prawa do wychowania podkreślono i doprecyzowano ponadto w art. 48 Konstytucji RP, gdzie zapisano: „Rodzice mają prawo do wychowania dzieci zgodnie z własnymi przekonaniami. Wychowanie to powinno uwzględniać stopień dojrzałości dziecka, a także wolność jego sumienia i wyznania oraz jego przekonania”.

Rodzice mają prawo podejmować działania zmierzające do kształtowania swoich dzieci pod względem psychicznym, umysłowym, duchowym, moralnym czy światopoglądowym w taki sposób, aby przygotować je do przyszłego, samodzielnego życia w społeczeństwie ${ }^{9}$. Ważnym zadaniem rodziców jest jednak również właściwe określenie momentu, od którego ich uprawnienia wychowawcze powinny powoli ustępować prawu samego dziecka do swobodnego wyboru wyznawanych przez nie wartości moralnych i przekonań religijnych.

Należy zatem stwierdzić, że w art. 48 i art. 53 Konstytucji RP zapewniono rodzicom pierwszeństwo w określaniu kierunku wychowania religijnego dzieci. Dotyczy to także szkoły, w której powinna zostać uszanowana wola katolickich rodziców, aby ich dzieci zostały wychowane po katolicku. Trzeba ponadto zauważyć, że w art. 47 Konstytucji RP zapewniono ochronę prawną życia rodzinnego.

\footnotetext{
6 Banaszak 2009, 274.

7 Konstytucja Polskiej Rzeczypospolitej Ludowej z dnia 22 lipca 1952 r., tekst jedn.
}

Dz. U. z 1976 r. Nr 7, poz. 36 z późn. zm.

Krukowski 2008, 63; Misztal 2011, 67-68.

9 Banaszak 2009, 250; Sztychmiler 2015b, 227-244. 
Istotne znaczenie dla rozwoju dziecka ma jego wychowanie w rodzinie. Zaakcentował to w swym orzecznictwie m.in. Trybunał Konstytucyjny, który w wyroku z dnia 28 kwietnia 2003 r. przyznał, iż ,najpełniejsza realizacja zasady dobra dziecka dokonywać się może poprzez zapewnienie możliwości jego wychowania się w rodzinie, przede wszystkim w rodzinie naturalnej, a więc poprzez pieczę rodzicielską sprawowaną przez osoby związane z dzieckiem więzią biologiczną" ${ }^{10}$. Chociaż prawodawca nie definiuje pojęcia rodziny, to ,z art. 18 Konstytucji RP, gdzie zapewnia jej szeroką ochronę i opiekę ze strony Rzeczypospolitej Polskiej, można wywnioskować, iż rodzinę tworzą małżonkowie, a jeśli mają dzieci - to stanowią one ją wspólnie z nimi. Rodzina to elementarny składnik struktury społecznej, wobec czego pełni podstawową rolę w wychowywaniu dzieci"11. Przepisy konstytucyjne uniemożliwiają narzucanie wzorców wychowawczych, kształtowanie postaw i przekonań dzieci wbrew woli rodziców, którym w tym zakresie zdecydowanie należy przyznać pierwszeństwo również dlatego, że ponoszą oni za to odpowiedzialnośćc ${ }^{12}$. Jak zwracał na to uwagę ks. prof. Henryk Misztal, „władza rodzicielska w tym przedmiocie płynie z prawa naturalnego i nie może być ograniczona ani przez szkołę, ani przez inne instytucje, chyba że rodzice wychowywaliby swoje dzieci w duchu poglądów sprzecznych z podstawowymi zasadami etyki i moralności"13.

Sformułowane w wyżej wymienionych przepisach uprawnienie rodziców do wychowania swoich dzieci jest równocześnie ich obowiązkiem, który szczegółowo uregulowany został w przepisach Kodeksu rodzinnego i opiekuńczego odnoszących się do władzy rodzicielskiej ${ }^{14}$. Zgodnie z jego art. $95 \S 1$ „władza rodzicielska obejmuje w szczególności obowiązek i prawo rodziców do wykonywania pieczy nad osobą i majątkiem dziecka oraz do wychowania dziecka". To na rodzicach więc pierwszorzędnie ciąży odpowiedzialność za prawidłowe ukształtowanie dziecka.

10 Wyrok Trybunału Konstytucyjnego z dnia 28 kwietnia 2003 r., K 18/02, OTK-A 2003, Nr 4, poz. 32.

11 Lach 2016, 56; Banaszak 2009, 119.

12 Winczorek 2000, 67.

13 Misztal 2000, 10.

14 Ustawa z dnia 25 lutego 1964 r. - Kodeks rodzinny i opiekuńczy, tekst jedn. Dz. U. z 2020 r., poz. 1359. 
Można stwierdzić, że gwarantowana każdemu człowiekowi wolność sumienia i religii jest fundamentem wszelkich wyznaniowych unormowań prawa polskiego. Debaty nad projektem obowiązującej Konstytucji RP, nad ratyfikacją Konwencji o prawach dziecka ${ }^{15}$ oraz nad przywróceniem nauczania religii w szkołach publicznych, doprowadziły przy tym do większego zainteresowania zagadnieniem wolności religijnej dziecka. I tak ks. prof. Józef Krukowski podkreśla, iż w sytuacji konfliktowej między rodzicami a dziećmi w sprawie spełniania praktyk religijnych pierwszeństwo w decydowaniu mają rodzice. Swoje stanowisko uzasadnia tym, iż pełną autonomię w dziedzinie wolności religijnej dzieci uzyskują dopiero w momencie ukończenia osiemnastego roku życia, czyli osiągnięcia pełnoletniości. Jednocześnie zaznacza, iż rodzice nie powinni stosować przymusu w stosunku do dzieci w tak delikatnej materii, lecz oddziaływać za pomocą swojego autorytetu, uwzględniając stopień dojrzałości dziecka ${ }^{16}$.

\section{POSTANOWIENIA PRAWA MIĘDZYNARODOWEGO}

Prawo międzynarodowe w niektórych aktach wyraźnie odnosi się do praw rodziców (i prawnych opiekunów) w zakresie wychowania dzieci zgodnego z ich własnymi przekonaniami religijnymi. Dokumenty prawa międzynarodowego, w których zagwarantowano wolność myśli, sumienia i religii w zdecydowanej większości podejmują także problematykę praw rodziców w zakresie moralnego i religijnego wychowania potomstwa ${ }^{17}$. Warto uważniej przyjrzeć się odnoszącym się do tego postanowieniom.

W art. 18 Powszechnej Deklaracji Praw Człowieka ONZ ${ }^{18}$ potwierdzono prawo każdego człowieka do wolności myśli, sumienia i religii. W omawianym dokumencie nie stanowi się wprost o prawach rodziców w odniesieniu do religijnego i moralnego wychowania potomstwa, ale można je wyinterpretować np. z art. 26 ust. 3, w którym uznano przysługujące

15 Konwencja o prawach dziecka przyjęta przez Zgromadzenie Ogólne Narodów Zjednoczonych dnia 20 listopada 1989 r., Dz. U. z 1991 r. Nr 120, poz. 526.

16 Krukowski 2008, 66.

17 Krajczyński 2005, 163-189.

18 Powszechna Deklaracja Praw Człowieka ONZ z dnia 10 grudnia 1948 r., w: Przyborowska-Klimczak 2003, 166-71. 
rodzicom ,prawo pierwszeństwa w wyborze rodzaju nauczania, które ma być dane ich dzieciom". To uprawnienie rodziców rozciąga się niewątpliwie także na nauczanie oraz wychowanie religijne i moralne ${ }^{19}$.

Wolność myśli, sumienia i religii zagwarantowana została również w Konwencji o Ochronie Praw Człowieka i Podstawowych Wolności ${ }^{20}$. W jej pierwotnych przepisach nie uwzględniono uprawnień rodziców w zakresie wychowania swych dzieci. Ten brak został jednak uzupełniony w Protokole dodatkowym nr $1^{21}$. W jego art. 2 postanowiono m.in., iż państwo, wykonując swoje funkcje w dziedzinie wychowania oraz nauczania, uznaje prawo rodziców do zapewnienia dzieciom wychowania i nauczania zgodnie z ich własnymi przekonaniami religijnymi i filozoficznymi. Jak wynika z orzecznictwa strasburskiego, nauczanie zorganizowane zgodnie z omawianym przepisem powinno być przede wszystkim wolne od indoktrynacji światopoglądowej2 ${ }^{22}$. Funkcje państwa ograniczają się tu więc do działalności gwarancyjno-organizatorskiej, opartej na zasadzie pomocniczości. Wybór wykształcenia należy wyłącznie do rodziców ${ }^{23}$.

W tym samym kierunku idą postanowienia Międzynarodowego Paktu Praw Obywatelskich i Politycznych ${ }^{24}$. Tu również potwierdza się najpierw prawo każdego człowieka „do wolności myśli, sumienia i wyznania” (art. 18 ust. 1). Odnosząc się natomiast do praw rodziców, strony tego Paktu zobowiązały się ,do poszanowania wolności rodziców lub w odpowiednich przypadkach opiekunów prawnych, do zapewnienia swoim dzieciom wychowania religijnego i moralnego zgodnie z własnymi przekonaniami" (art. 18 ust. 4). W dalszych postanowieniach omawianej umowy międzynarodowej (art. 23 ust. 1) podkreślono ponadto, że rodzina jest „,naturalną i podstawową komórką społeczeństwa" i ma prawo do ochrony ze strony

19 Krukowski 2000, 211.

20 Konwencja o Ochronie Praw Człowieka i Podstawowych Wolności z dnia 4 listopada 1950 r., Dz. U. z 1993 r. Nr 61, poz. 284.

21 Protokół nr 1 do Konwencji o ochronie praw człowieka i podstawowych wolności, sporządzony w Paryżu dnia 20 marca 1952 r. oraz Protokół nr 4 do powyższej konwencji, sporządzony w Strasburgu dnia 16 września 1963 r., Dz. U. z 1995 r. Nr 36, poz. 175.

22 Czuryk 2013, 57.

23 Warchałowski 2007, 204.

24 Międzynarodowy Pakt Praw Obywatelskich i Politycznych z dnia 16 grudnia 1966 r., Dz. U. z 1977 r. Nr 38, poz. 167. Został ratyfikowany przez Polskę 3 marca 1977 r. 
społeczeństwa i państwa. Niewątpliwie to właśnie rodzina jest najlepszym środowiskiem wychowania religijnego i moralnego.

Międzynarodowy Pakt Praw Gospodarczych, Społecznych i Kulturalnych ${ }^{25}$ reguluje kwestię wolności wyboru szkoły zgodnie z przekonaniami religijnymi rodziców (bądź prawnych opiekunów), a także wieloaspektowo traktuje o prawach rodziców i dzieci. Państwa-Strony zobowiązały się w nim również expressis verbis, że będą szanować wolność rodziców lub prawnych opiekunów w zakresie ,zapewnienia swoim dzieciom wychowania religijnego i moralnego zgodnie z własnymi przekonaniami" (art. 13 ust. 3).

Omawiana problematyka została podjęta również w Konwencji w sprawie zwalczania dyskryminacji w dziedzinie oświaty ${ }^{26}$. W art. 5 ust. 1 lit. b tej umowy postanowiono m.in., że „,rodzice i w odpowiednich przypadkach prawni opiekunowie powinni mieć możność [...] zapewnienia religijnego i moralnego wychowania dzieci zgodnie z ich osobistymi przekonaniami”. Trzeba więc stwierdzić, że przepis ten (a także inne) ,daje rodzicom jednoznaczne prawo pierwszeństwa w wychowaniu i nauczaniu dzieci. Państwo i jego instytucje mają prawo jedynie pomagać, i to w stopniu, w jakim sobie tego życzą i potrzebują rodzice"27.

Kolejnym aktem, na który należy zwrócić uwagę, jest Deklaracja w sprawie likwidacji wszystkich form nietolerancji i dyskryminacji ze względu na wyznawaną religię lub wierzenia ${ }^{28}$. Zapisano w niej, że rodzice mają prawo do organizowania swojego życia w obrębie rodziny zgodnie z ich religią lub przekonaniami. Do nich także należy decyzja dotycząca edukacji moralnej, w której dziecko powinno wzrastać (art. 5 ust. 1). Natomiast dzieci uprawnione są do korzystania z dostępu do edukacji w dziedzinie religii lub przekonań zgodnie z życzeniem ich rodziców. Zaznaczono

25 Międzynarodowy Pakt Praw Gospodarczych, Społecznych i Kulturalnych z dnia 16 grudnia 1966 r., Dz. U. z 1977 r. Nr 38, poz. 169. Został ratyfikowany przez Polskę 3 marca $1977 \mathrm{r}$.

26 Konwencja w sprawie zwalczania dyskryminacji w dziedzinie oświaty, sporządzona w Paryżu dnia 15 grudnia 1960 r., Dz. U. z 1964 r. Nr 40, poz. 268.

27 Kroczek 2013, 56.

28 Deklaracja w sprawie likwidacji wszystkich form nietolerancji i dyskryminacji ze względu na wyznawaną religię lub wierzenia z dnia 25 listopada 1981 r., w: Zubik (red.) 2008, 155-158. 
przy tym, że dziecko nie może być zmuszane do pobierania nauki o religii lub przekonaniach wbrew woli jego rodziców (art. 5 ust. 2). Przepisy te oznaczają, iż rodzice powinni być jedynymi decydentami w kwestiach nauczania oraz wychowania religijnego i moralnego ich dzieci.

Szczególnie istotne miejsce wśród dokumentów odnoszących się do sytuacji prawnej dzieci zajmuje wspomniana wyżej Konwencja o prawach dziecka. Zgodnie z jej postanowieniami Państwa-Strony zobowiązały się m.in. do respektowania praw i obowiązków rodziców odnośnie do ukierunkowania dziecka w korzystaniu z jego prawa do wolności religijnej w sposób zgodny z jego rozwijającymi się zdolnościami. W art. 5 tej Konwencji ujęto istotną zasadę uznającą wpływ rodziców na realizację uprawnień przez dziecko. Treścią omawianego postanowienia jest bowiem obowiązek respektowania odpowiedzialności, praw i obowiązków rodziców w odniesieniu do ukierunkowywania dziecka i udzielania mu rad przy korzystaniu przez nie z praw gwarantowanych mu przez Konwencję. Tym samym Konwencja wskazuje, iż obowiązkiem rodziców jest udzielanie dziecku pomocy w urzeczywistnianiu jego uprawnień. Ważna dla omawianej kwestii jest również regulacja zawarta w art. 18 ust. 1 Konwencji, wedle której rodzice wspólnie ponoszą główną odpowiedzialność za wychowanie i rozwój dziecka, a jak najlepsze zabezpieczenie jego interesów ma być przedmiotem ich największej troski.

Ratyfikacja Konwencji o prawach dziecka sprawiła, iż poszczególne państwa zaczęły także dziecko uznawać za podmiot określonych praw. W dokumencie tym expressis verbis proklamowano również wolność religijną dziecka, uznając jednocześnie prawa i obowiązki rodziców lub opiekunów prawnych w zakresie ustalania zasad korzystania przez nie z przysługujących mu uprawnień (art. 14). Adresatami norm proklamujących prawo dziecka do wolności religijnej są nie tylko dzieci, ale także rodzice, organy państwa, nauczyciele i inni pracownicy oświaty oraz osoby trzecie, które mają wpływ na sytuację dziecka. Dziecko nie jest bowiem podmiotem samodzielnym w korzystaniu z wolności. Ma ono prawo do wolności religii, ale sposób realizacji tego prawa jest zależny od jego rodziców. W art. 14 ust. 3 Konwencji przewidziano możliwość ograniczenia wolności religijnej dziecka, bowiem nie jest ona absolutna ${ }^{29}$. Polska ratyfikując tę

29 Lach 2016, 26-27. 
Konwencję złożyła deklarację, zgodnie z którą korzystanie przez dziecko m.in. z prawa do wolności myśli, sumienia i religii „,dokonuje się z poszanowaniem władzy rodzicielskiej, zgodnie z polskimi zwyczajami i tradycjami dotyczącymi miejsca dziecka w rodzinie i poza rodziną"30.

Trzeba wreszcie zauważyć, że kwestia prawa rodziców do wychowania dzieci zgodnie z własnymi przekonaniami nie została pominięta również w Karcie Praw Podstawowych Unii Europejskiej ${ }^{31}$. Obok wolności myśli, sumienia i religii, którą zagwarantowano każdemu człowiekowi, wyraźnie - choć z odniesieniem się do ustaw krajowych regulujących korzystanie z tego prawa - uznano prawo rodziców do zapewnienia wychowania i nauczania dzieci zgodnie z własnymi przekonaniami religijnymi, filozoficznymi i pedagogicznymi.

Ważne postanowienia dotyczące wychowania religijnego i nauczania religii zawiera Konkordat między Stolicą Apostolską i Rzecząpospolitą Polską podpisany dnia 28 lipca 1993 r. $^{32}$ i ratyfikowany w dniu 23 lutego 1998 r. przez Ojca Świętego Jana Pawła II ze strony Stolicy Apostolskiej oraz prezydenta Aleksandra Kwaśniewskiego ze strony Rzeczypospolitej Polskiej. Unormowania dotyczące tej problematyki zawarto w art. 12-15 tej umowy międzynarodowej. Wychodząc od uznania prawa rodziców do religijnego wychowania dzieci i zasady tolerancji postanowiono przede wszystkim, że w szkołach publicznych podstawowych i ponadpodstawowych, a także w przedszkolach prowadzonych przez organy administracji państwowej i samorządowej, zgodnie z wolą zainteresowanych i w ramach planu zajęć szkolnych i przedszkolnych, ma być organizowana nauka religii (art. 12). Dzieciom i młodzieży katolickiej, korzystającym z różnych form zbiorowego wypoczynku, zapewniono możliwość wykonywania praktyk religijnych, a zwłaszcza uczestniczenia we Mszy św. w niedziele i święta (art. 13). Kościołowi Katolickiemu zapewniono prawo zakładania i prowadzenia placówek oświatowych i wychowawczych, w tym przedszkoli

30 Zob. tamże, 27-28.

31 Karta Praw Podstawowych Unii Europejskiej, Dz. Urz. UE C 326 z 7.06.2012 r.

32 Konkordat między Stolicą Apostolską i Rzecząpospolitą Polską podpisany dnia 28 lipca 1993 r., Dz. U. z 1998 r. Nr 51, poz. 318. 
i szkół (art. 14), a także prawo do swobodnego zakładania i prowadzenia różnego rodzaju szkół wyższych (art. 15) ${ }^{33}$.

Podsumowując dokonany przegląd można stwierdzić, iż wszystkie najistotniejsze akty prawa międzynarodowego, których przedmiotem jest ochrona praw człowieka, mają klauzule dotyczące wolności myśli, sumienia i religii ${ }^{34}$. W wielu z nich wyraźnie uznano prawo rodziców do decydowania o kierunku wychowania religijnego i moralnego swoich dzieci. Należy podkreślić, że znaczenie tego prawa nie ogranicza się do środowiska domowego, ale dotyczy też szkół i innych placówek publicznych. Warto też zauważyć, że stanowisko to jest zbieżne z treścią Karty Praw Rodziny, która została ogłoszona przez Stolicę Apostolską w 1983 r. ${ }^{35} \mathrm{~W}$ art. 5 tego dokumentu wyraźnie podkreślono, iż rodzice mają pierwotne, niezbywalne prawo i pierwszeństwo do wychowania potomstwa, zatem mogą kształtować dzieci zgodnie ze swoimi przekonaniami moralnymi i religijnymi. Winni przy tym uwzględniać tradycje kulturalne rodziny, które sprzyjają dobru i godności dziecka. Dodatkowo istotne w świetle aktualnych problemów dotyczących edukacji seksualnej w szkołach jest zastrzeżenie, iż wychowanie seksualne stanowi podstawowe prawo rodziców i powinno dokonywać się zawsze pod ich troskliwym kierunkiem zarówno w domu, jak też wybranych i kontrolowanych przez nich ośrodkach wychowawczych. Zgodnie z treścią Karty to do rodziców należy decydowanie o organizowaniu życia religijnego w ramach rodziny (art. 7).

\section{USTAWODAWSTWO POLSKIE}

Każdy człowiek w Polsce ma prawo do uzewnętrzniania swoich przekonań religijnych. Prawo to może być realizowane w różnej postaci, np. poprzez nauczanie lub udział w nauczaniu religii, które może być realizowane również $\mathrm{w}$ ramach systemu oświaty ${ }^{36}$. O możliwości nauczania religii

33 Zob. Sztychmiler 2002, 116-122.

34 Lach 2016, 24.

35 Carta dei Diritti della Famiglia presentata dalla Sante Sede a tutte le persone, istituzioni ed autorità interessate alla missione della famiglia nel mondo di oggi (22.10.1983), „Communicationes” 15 (1983), nr 2, 140-152; tekst polski: Lubowicki 1999, 239-250.

36 Mezglewski 2011, 95-96. 
przez kościoły i inne związki wyznaniowe wyraźnie stanowi art. 20 ustawy z dnia 17 maja 1989 r. o gwarancjach wolności sumienia i wyznania ${ }^{37}$. Przewidziano tu także, że nauczanie religii może się odbywać w szkołach i przedszkolach, co potem wyniesione zostało na poziom konstytucyjny (art. 53 ust. 4 Konstytucji RP). Wynika z niego również prawo do religijnego wychowywania dzieci i młodzieży. Omawiana ustawa nie odnosi się expressis verbis do dziecka jako podmiotu wolności religijnej, a wskazuje prawo rodziców do wychowania dzieci zgodnie z własnymi przekonaniami w sprawach religii (art. 2 pkt 4). Wynika stąd niewątpliwie również prawo dzieci do korzystania z nauczania religii, jednak decyzji tego dotyczących (przed osiągnięciem pełnoletniości) nie mogą podejmować samodzielnie $^{38}$. Prawo do podjęcia decyzji o uczęszczaniu przez dziecko na lekcje religii w przedszkolu czy szkole posiadają rodzice, bo to oni są uprawnieni do decydowania o kierunku wychowania moralnego i religijnego swoich dzieci ${ }^{39}$. W orzeczeniu z dnia 30 stycznia z $1991 \mathrm{r}$. Trybunał Konstytucyjny wskazał przy tym, iż „świeckość i neutralność [państwa] nie tylko nie może być podstawą do wprowadzania obowiązku nauczania religii w szkołach państwowych, ale także nie może oznaczać zakazu takiego nauczania, jeśli życzą sobie tego zainteresowani obywatele"40.

Zgodnie $\mathrm{z}$ art. 53 ust. 4 Konstytucji RP przedmiotem nauczania w szkole może być religia kościoła lub innego związku wyznaniowego o uregulowanej sytuacji prawnej. Przyjmuje się, że status takiego podmiotu jest uregulowany wówczas, gdy podstawę jego działania stanowi ustawa określająca jego stosunki z państwem, albo który jest wpisany do rejestru prowadzonego przez ministra właściwego do spraw wyznań religijnych ${ }^{41}$.

Z konstytucyjnym przepisem umożliwiającym nauczanie religii w szkołach wiążą się dwa ważne obowiązki spoczywające na państwie. Pierwszy z nich polega na finansowaniu przez państwo nauczania religii w sposób analogiczny do finansowania innych przedmiotów nauczania,

37 Ustawa z dnia 17 maja 1989 r. o gwarancjach wolności sumienia i wyznania, tekst jedn. Dz. U. z 2017 r., poz. 1153.

38 Pietrzak 2010, 260.

39 Krukowski 1991, 8-13.

40 Orzeczenie Trybunału Konstytucyjnego z dnia 30 stycznia z 1991 r., K 11/90, OTK 1991, Nr 1, poz. 2. Zob. Mezglewski 2000, 105-108.

41 Banaszak 2009, 274. 
natomiast drugi polega na zapewnieniu realizacji tego nauczania w sensie organizacyjnym. Państwo nie może ingerować w treści, które są przekazywane w ramach nauczania religii, gdyż są one ustalane przez władze odpowiednich kościołów i innych związków wyznaniowych. Nie uprawnia ich to jednak oczywiście do przekazywania treści niezgodnych z prawem, a odpowiednie władze państwowe mają prawo do prowadzenia ogólnego (pedagogicznego) nadzoru nad procesem nauczania, tak jak w przypadku innych przedmiotów szkolnych ${ }^{42}$.

Również zgodnie z ustawą z dnia 7 września 1991 r. o systemie oświaty ${ }^{43}$ prawo do nauczania religii odnosi się nie tylko do pomieszczeń kościelnych, lecz także do szkół i przedszkoli publicznych ${ }^{44}$. Natomiast zgodnie ze wstępem ustawy z dnia 14 grudnia 2016 r. - Prawo oświatowe ${ }^{45}$ „nauczanie i wychowanie - respektując chrześcijański system wartości - za podstawę przyjmuje uniwersalne zasady etyki”. Jest przy tym jednak jasne, że organizując nauczanie religii należy zachować zasadę jego dobrowolności ${ }^{46}$.

Zgodnie z art. 12 ustawy o systemie oświaty (którego treść została powtórzona w rozporządzeniu Ministra Edukacji Narodowej z dnia 14 kwietnia $1992 \mathrm{r}^{47}$ ) w publicznych przedszkolach i szkołach podstawowych naukę religii organizuje się na życzenie rodziców, natomiast w szkołach ponadpodstawowych dokonuje się to na życzenie rodziców bądź samych uczniów. Czytelnie przy tym postanowiono, że - bez względu na poziom nauczania - ,po osiągnięciu pełnoletności o pobieraniu nauki religii decydują uczniowie". Unormowania te pozwalają na stwierdzenie, że religia ma w polskim systemie oświaty charakter przedmiotu fakultatywnego,

42 Mezglewski 2009, 150-158; Banaszak 2009, 275; Grześkowiak 1991, 41-51; Sztychmiler 2015a, 13-30.

43 Ustawa z dnia 7 września 1991 r. o systemie oświaty, tekst jedn. Dz. U. z 2021 r., poz. 1915.

44 Dobkowski 2018, 159-161.

45 Ustawa z dnia 14 grudnia 2016 r. - Prawo oświatowe, tekst jedn. Dz. U. z 2021 r., poz. 1082 .

46 Milerski 2009, 333-341.

47 Rozporządzenie Ministra Edukacji Narodowej z dnia 14 kwietnia 1992 r. w sprawie warunków i sposobu organizowania nauki religii w publicznych przedszkolach i szkołach, tekst jedn. Dz. U. z 2020 r., poz. 983. 
a wolność sumienia i wyznania dzieci, rozważana w powiązaniu z prawami należnymi rodzicom, jest w pełni uszanowana ${ }^{48}$.

Należy stwierdzić, że wszystkim dzieciom w Polsce zapewniono możliwość korzystania z nauczania religii w szkołach w równym stopniu, niezależnie od wyznania (zwłaszcza że w 2014 r. zniesiono limit uczniów odnoszący się do nauczania w grupie międzyszkolnej lub pozaszkolnych punkcie katechetycznym ${ }^{49}$ ). Nie ma przeszkód, by w jednej szkole odbywały się zajęcia z religii różnych związków wyznaniowych, co ma znaczenie zwłaszcza na terenach zróżnicowanych kulturowo ${ }^{50}$.

Zgodnie z powoływanym wyżej rozporządzeniem z 1992 r., „w pomieszczeniach szkolnych może być umieszczony krzyż”. Należy w związku z tym przypomnieć, że sprawa obecności krzyży (ściślej - krucyfiksów) w salach szkolnych była rozpatrywana przez Europejski Trybunał Praw Człowieka. Wielka Izba w wyroku z dnia 18 marca 2011 r. stwierdziła, iż taka obecność nie wiąże się z wywieraniem niedopuszczalnej presji na uczniów i zakazaną indoktrynacją ze strony państwa ${ }^{51}$.

\section{WNIOSKI}

Rodzice mają naturalne prawo podejmowania działań zmierzających do ukształtowania swoich dzieci pod względem psychicznym, umysłowym, duchowym, moralnym, światopoglądowym i religijnym. Słusznie znalazło to odzwierciedlenie w polskich przepisach konstytucyjnych, wśród których najważniejsze są normy zapisane w art. 48 i art. 53 Konstytucji RP. Uniemożliwiają one narzucanie wzorców wychowawczych, kształtowanie postaw i przekonań dzieci wbrew woli rodziców, którym zdecydowanie przysługuje pierwszeństwo jeśli chodzi o określanie kierunku wychowania religijnego i moralnego swoich dzieci. Również postanowienia

48 Krukowski 2003, 12; Łączkowski 1991, 69-83; Kędziora 2015, 147-156.

49 Dokonało się to na mocy rozporządzenia Ministra Edukacji Narodowej z dnia 25 marca 2014 r. zmieniającego rozporządzenie w sprawie warunków i sposobu organizowania nauki religii w publicznych przedszkolach i szkołach, Dz. U. z 2014 r., poz. 478.

50 Winczorek 2000, 74; Michalski 2006, 49-60; Sobczyk 2008, 211-227; Stawniak 2007, 32-48.

51 Tekst polski: „Przegląd Prawa Wyznaniowego” 2011, t. 3, s. 157-210. 
umów międzynarodowych poświęconych ochronie praw człowieka nie ograniczają się z reguły do generalnego zagwarantowania wolności myśli, sumienia i religii każdemu człowiekowi. Zawierają też zazwyczaj postanowienia chroniące prawo rodziców do decydowania o kierunku wychowania moralnego i religijnego swego potomstwa. W zgodzie z tymi standardami ukształtowano przepisy ustaw oraz wydanych na ich podstawie aktów wykonawczych. Niezależnie od wyznania wszystkim zapewniono w szczególności możliwość korzystania z nauczania religii w szkołach. Można więc stwierdzić, że prawo rodziców do religijnego wychowania swych dzieci korzysta w Polsce z dość szerokiej ochrony. Jej ewentualne niedostatki mogą wynikać z niewłaściwego stosowania prawa. Kwestia ta zasługuje jednak na osobną analizę.

\section{BIBLIOGRAFIA}

Banaszak, Bogusław. 2009. Konstytucja RP. Komentarz. Warszawa: C.H. Beck. Czuryk, Małgorzata. 2013. Ochrona prawa rodziców do wychowania dzieci zgodnie z własnymi przekonaniami religijnymi i filozoficznymi w systemach edukacji publicznej państw członkowskich Unii Europejskiej. Warszawa: Wydawnictwo Akademii Obrony Narodowej.

Dobkowski, Jarosław. 2018. „Zakres działania wspólnot religijnych w sferze administracji publicznej ze szczególnym uwzględnieniem spraw małżeństwa i rodziny". W: Prawo w stużbie matżeństwu i rodzinie. Księga jubileuszowa dedykowana ks. prof. dr. hab. Ryszardowi Sztychmilerowi z okazji 70. rocznicy urodzin, red. Mieczysław Różański, Justyna Krzywkowska, Magdalena Rzewuska, 153-164. Olsztyn: Wydział Prawa i Administracji UWM.

Grześkowiak, Alicja. 1991. „Religia w szkole a prawa człowieka”. W: Nauczanie religii $w$ szkole $w$ państwie demokratycznym, red. Józef Krukowski, 41-51. Lublin: Towarzystwo Naukowe KUL.

Grześkowiak, Alicja. 1994. „Konkordat a prawo do religii”. W: Prawda o konkordacie, red. Wojciech Góralski, 59-68. Częstochowa: „Niedziela”.

Kędziora, Paweł. 2015. „Wychowanie religijne a nauczanie religii w szkołach publicznych". W: Wychowanie religijne i moralne, red. Mieczysław Różański, Ryszard Sztychmiler, 147-156. Olsztyn: Wydział Prawa i Administracji UWM.

Krajczyński, Jan. 2005. „Wychowanie dziecka w prawie kanonicznym, polskim i wspólnotowym". Studia z Prawa Wyznaniowego 8: 163-189. 
Kroczek, Piotr. 2013. Wychowanie. Optyka prawa polskiego i prawa kanonicznego. Kraków: Wydawnictwo Naukowe Uniwersytetu Papieskiego Jana Pawła II.

Krukowski, Józef. 1991. „Stanowisko Kościoła katolickiego w sprawie nauczania religii w szkołach". W: Nauczanie religii w szkole w państwie demokratycznym, red. Józef Krukowski, 7-24. Lublin: Towarzystwo Naukowe KUL.

Krukowski, Józef. 2000. Kościót i państwo. Podstawy relacji prawnych. Lublin: Redakcja Wydawnictw KUL.

Krukowski, Józef. 2003. „Ochrona wolności myśli, sumienia i religii dziecka”. Roczniki Nauk Prawnych 13/2: 5-18.

Krukowski, Józef. 2008. Polskie prawo wyznaniowe. Warszawa: Wolters Kluwer.

Lach, Izabela. 2016. Dziecko jako podmiot wolności sumienia i wyznania. Warszawa: C.H. Beck.

Lubowicki, Kazimierz (oprac.). 1999. Posoborowe dokumenty Kościoła katolickiego i matżeństwie i rodzinie. Kraków: Wydawnictwo M.

Łączkowski, Wojciech. 1991. „Stanowisko Trybunału Konstytucyjnego w sprawie legalności instrukcji MEN dotyczących powrotu nauczania religii do szkoły w roku szkolnym 1990/91". W: Nauczanie religii w szkole w państwie demokratycznym, red. Józef Krukowski, 69-83. Lublin: Towarzystwo Naukowe KUL.

Mezglewski, Artur. 2000. „Usunięcie i przywrócenie nauczania religii do szkół”. W: Katecheza dzisiaj. Problemy prawne i teologiczne, red. Waldemar Janiga, Artur Mezglewski, 97-108. Krosno - Sandomierz: Wydawnictwo Diecezjalne w Sandomierzu.

Mezglewski, Artur. 2009. Polski model edukacji religijnej w szkołach publicznych. Aspekty prawne. Lublin: Wydawnictwo KUL.

Mezglewski, Artur. 2011. „Podstawowe formy uzewnętrzniania przekonań religijnych". W: Artur Mezglewski, Henryk Misztal, Piotr Stanisz, Prawo wyznaniowe, 94-98. Warszawa: C.H. Beck.

Michalski, Jarosław. 2006. „Jakie wychowanie religijne w epoce ponowoczesnej?". Acta Universitatis Nicolai Copernici. Nauki Humanistyczno-Społeczne. Socjologia Wychowania 16: 49-60.

Milerski, Bogusław. 2009. „Edukacja religijna w szkole neutralnej światopoglądowo". W: Pro bono Reipublicae. Ksiega jubileuszowa Profesora Michata Pietrzaka, red. Paweł Borecki, Andrzej Czohara, Tadeusz J. Zieliński, 333-341. Warszawa: LexisNexis.

Misztal, Henryk. 2000. „Gwarancje prawa międzynarodowego i polskiego w zakresie uprawnień rodziców do religijnego wychowania dzieci”. Studia z Prawa Wyznaniowego 1: 5-20. 
Misztal, Henryk. 2011. „Konstytucyjne gwarancje wolności sumienia i religii”. W: Artur Mezglewski, Henryk Misztal, Piotr Stanisz, Prawo wyznaniowe, 66-73. Warszawa: C.H. Beck.

Pietrzak, Michał. 2010. Prawo wyznaniowe. Warszawa: Wolters Kluwer.

Przyborowska-Klimczak, Anna. 1998. Prawo międzynarodowe publiczne. Wybór dokumentów. Lublin: Lubelskie Wydawnictwa Prawnicze.

Sobczyk, Paweł. 2008. „Wolność religijna a nauczanie w szkole”. Prawo Kanoniczne 51/1-2: 211-227.

Stawniak, Henryk. 2007. „Prawa i obowiązki rodziców w kontekście zadań szkoły". Prawo Kanoniczne 50/3-4: 31-49.

Sztychmiler, Ryszard. 2002. „Ochrona praw człowieka w normach konkordatu polskiego z 1993 roku". W: Ochrona człowieka w świetle prawa Rzeczypospolitej Polskiej. Materiaty z II Międzynarodowej Konferencji Naukowej, Mierki 18-19 października 2001, red. Stanisław Pikulski. Olsztyn: Wydawnictwo UWM.

Sztychmiler, Ryszard. 2015a. „Komplementarne obowiązki rodziców i państwa względem chrześcijańskiego wychowania dzieci. Rozwój norm od Soboru Watykańskiego II do Kodeksu Prawa Kanonicznego". W: Wychowanie religijne i moralne, red. Mieczysław Różański, Ryszard Sztychmiler, 13-30. Olsztyn: Wydział Prawa i Administracji UWM.

Sztychmiler, Ryszard. 2015b. „Konstytucyjna ochrona małżeństwa i rodziny a ekspansja gender". Studia Prawnoustrojowe 27: 227-244.

Warchałowski, Krzysztof. 2007. „Gwarancje prawa do wychowania religijno-moralnego w umowach międzynarodowych". Studia z Prawa Wyznaniowego 10: 201-208.

Winczorek, Piotr. 2000. Komentarz do Konstytucji Rzeczypospolitej Polskiej $z$ dnia 2 kwietnia $1997 r$. Warszawa: Liber.

Zubik, Marek (red.). 2008. Wybór dokumentów prawa międzynarodowego dotyczacych praw człowieka. Warszawa: Biuro Rzecznika Praw Obywatelskich. 